4. Emergency Management Australia. EMA Disasters Database. 2008. http:// www.ema.gov.au/ema/emadisasters.nsf/83edbd0553620d8cca256d09001fc8fd/ a938782910c99ec7ca257346001736de?OpenDocument. Accessed December 2010.

5. Frontier Economics. Benefits and costs related to Victorian management of equine influenza. A final report prepared for the Victorian Department of Primary Industries. 2008. http://www.dpi.vic.gov.au/dpi/nrensr.nsf/LinkView/ 91B05D0D1F10C984CA257501001AEACD26200B8A5DC746B0CA2573A3000

E1592/\$file/Frontier\%20Economics\%20-\%20Equine\%20Influenza\%20\%20final\%20for\%20release\%20NOV\%2008.pdf. Accessed December 2010.

6. Racing and Wagering Western Australia. Submission to the Senate Rural and Regional Affairs and Transport Committee for the inquiry into the Australian horse industry and an emergency animal disease response agreement. 2010. http://www.aph.gov.au/Senate/committee/rrat_ctte/oz_horse_industry/report/ attachment.pdf. Accessed September 2010.

7. Callinan I. Equine influenza: The 2007 outbreak in Australia. Report of the Equine Influenza Inquiry. 2008. http://www.equineinfluenzainquiry.gov.au/. Accessed December 2010.

8. Australian Government Attorney-General's Department. Annual Report 2007-2008. 2008. http://www.ag.gov.au/www/agd/agd.nsf/Page/Publications Annual_ReportsAnnual_Report_2007. Accessed August 2010.

9. Shergold P. Fifth report to the Minister for Agriculture, Fisheries and Forestry, The Hon. Tony Burke MP on the implementation of the Callinan inquiry. 2010.
http://www.daff.gov.au/_data/assets/pdf_file/0005/1767551/Prof-Shergold5th-report.pdf. Accessed October 2010.

10. Australian Horse Industry Council. Equine influenza impact study. http://www.horsecouncil.org.au/content.asp? $z=26 \& c=149 \& p=408$. Accessed December 2010.

11. Australian Horse Industry Council. Follow up equine influenza impact study. 2008. http://www.horsecouncil.org.au/content.asp?z=26\&c=149\&p=413. Accessed December 2010.

12. Australian Horse Industry Council. AHIC survey about horse deaths and veterinary expenses due to equine influenza in Australia. AHIC, Geelong, 2008.

13. Smyth GB, Dagley K. Internet-based survey of Australian horse owners for mortality and morbidity related to equine influenza in the 2007 Australian epidemic. Aust Vet J 2011;89(Suppl 1):23-25.

14. Animal Health Australia. Disease strategy: El (Version 3.0). In: Australian Veterinary Emergency Plan (AUSVETPLAN), edn 3. Primary Industries Ministerial Council, Canberra, 2007.

15. Nixon C. An economic analysis of the impacts of equine influenza in New Zealand: Report to Biosecurity New Zealand. New Zealand Institute of Economic Research, Wellington, 2007.

16. Primary Industries Ministerial Council. Record and resolutions: $15^{\text {th }}$ meeting. 2009. http://www.mincos.gov.au/_data/assets/pdf_file/0009/1767051/pimc15-long-resol.pdf. Accessed December 2010.

\title{
Factors associated with high psychological distress in horse industry participants during the 2007 Australian equine influenza outbreak and evidence of recovery after 1 year
}

\author{
M Taylor,* K Agho, G Stevens and B Raphael
}

This short report summarises data on the prevalence of high psychological distress in horse industry participants during the 2007 Australian equine influenza (EI) outbreak and the statistical analysis undertaken to identify the factors associated with this high psychological distress. In addition, follow-up data collected 1 year later are reported briefly.

Keywords equine influenza; horse industry; psychosocial effects

Abbreviations $\mathrm{Cl}$, confidence interval; $\mathrm{El}$, equine influenza; $\mathrm{K} 10$, Kessler 10; OR, odds ratio

Aust Vet $J$ 2011;89(Suppl 1):158-159

doi: 10.1111/j.1751-0813.2011.00772.x

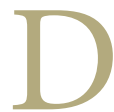

uring Australia's first outbreak of EI in August 2007, government and the horse industry cooperated to put in place measures to control, contain and eradicate the disease. These measures included movement restrictions and quarantining of horse properties. This 'Human Impacts of Equine Influenza' study was conducted to assess the psychosocial effects of the disease outbreak and the control response.

*Corresponding author

School of Medicine, University of Western Sydney, Penrith South DC, New South Wales 1797, Australia; melanie.taylor@uws.edu.au

\section{Materials and methods}

Data were collected using an online survey. A link to the survey was sent out by the Australian Horse Industry Council to all recipients registered on the Horse Emergency Contact Database, which included individual horse owners and a number of horse industry groups and associations. Psychological distress was measured using the Kessler 10 (K10), a 10-item standardised measure used in research and many Australian population health surveys. The K10 produces a composite score between 10 and 50, with high psychological distress categorised as scores $\geq 22$. Very high levels (scores $\geq 30$ ) are recognised as indicative of a diagnosable mental disorder. The K10 measure includes components of anxiety and depression. The prevalence of high psychological distress in the Australian general population is around $11-13 \%$.

\section{Results}

Data were collected during the EI outbreak from 15 November to the end of December 2007 and 2760 sets of complete data were analysed. Respondents were from all states and territories, with twothirds from New South Wales and Queensland. Extremely high levels of psychological distress were reported by respondents, with $34 \%$ reporting high psychological distress (scores $\geq 22$ ). After controlling 
for potential confounders, multivariate analysis revealed that those living in high risk infection (Red) zones (odds ratio (OR) 2.00; 95\% confidence interval (CI) 1.57-2.55; $\mathrm{P}<0.001)$ and disease buffer (Amber) zones (OR 1.83; 95\% CI 1.36-2.46; P < 0.001) were at much greater risk of high psychological distress than those living in uninfected (White) zones. Even so, elevated levels of psychological distress were experienced by horse-owners nationally. Statistical analysis indicated that certain groups were more vulnerable to high psychological distress; specifically, younger people and those with lower levels of formal education. Respondents whose principal source of income was from horse industry-related activities were more than twice as likely to have high psychological distress than those whose income was not linked to these activities (OR 2.23; 95\% CI: $1.82-2.73$; $\mathrm{P}<0.001)$. Further details of the analysis of the psychological distress data from the 2007 study have been published elsewhere. ${ }^{1}$

Follow-up data were collected in December 2008 from 1011 respondents who had taken part in the first survey. Data for this matched group indicated that high psychological distress levels reduced from $36 \%$ in 2007 to $28 \%$ in 2008 . Preliminary analysis using a paired t-test indicated that the mean K10 score reduced significantly from 2007 to 2008 (2007: 20.07, 95\% CI 19.47-20.67; 2008: 18.60, $95 \%$ CI 18.03-19.16, P $<0.0001)$. Repeat multivariate analysis indicated that the EI control zone was no longer a significant factor. Although most groups showed noticeable reductions in high psychological distress, no evidence of recovery was noted for the youngest age group in the sample (16-24 year olds). Reported psychological distress in this group persisted at very high levels, around $50 \%$.

\section{Conclusion}

Data from this study indicate an effect of EI on the psychological health and well-being of horse owners and horse industry participants during the outbreak. Those with financial dependence on the horse industry, with lower levels of formal education, in a young age group and those in more restricted EI control zones reported higher levels of psychological distress. One year after the first study there is evidence of recovery and specific EI-related factors are no longer associated with differences in psychological distress in the sample. However, distress levels appear to be persisting in younger respondents and this finding requires further investigation. Although methodologically this study has limitations, such as issues of general application because of sampling limitations, it does have good internal validity. The study findings may be used to inform those involved in assessing the potential psychological effects of not only animal disease control, but also human infectious disease control.

\section{Disclosures}

The authors have no competing interests to disclose.

\section{Reference}

1. Taylor MR, Agho KE, Stevens GJ, Raphael B. Factors influencing psychological distress during a disease epidemic: Data from Australia's first outbreak of equine influenza. BMC Public Health 2008;8:347. www.biomedcentral. com/14712-458/8/ 347. Retrieved July 2010.

\title{
An insider's view of the lockdown at Moonbi during the Australian equine influenza outbreak
}

\author{
M Drury
}

Participants in the 1- and 2-day Tamworth Dressage Club (TDC) annual dressage championships arrived in Moonbi, New South Wales (NSW) as reports of the equine influenza outbreak surfaced on 25 August 2007. Three horses who had attended a competition in Maitland the weekend before had been showing flu-like symptoms and the next day the site was declared a suspect premise. On 27 August, infection was confirmed and the site was placed in total quarantine. Although most participants had travelled long distances to compete and did not have provisions for them or their horses, the quarantine was not lifted until 3 October, having a great social and personal impact on all those trapped in Moonbi.

Tamworth Dressage Club, Moonbi, New South Wales 2353, Australia; gillabri@ bigpond.com
Keywords biosecurity; equine influenza; horse industry; psychosocial effects

Abbreviations DPI, Department of Primary Industries; El, equine influenza; NSW, New South Wales; RLPB, Rural Lands Protection Board; SDCHQ, State Disease Control Head Quarters; TDC, Tamworth Dressage Club

Aust Vet J 2011;89(Suppl 1):159-161

doi: 10.1111/j.1751-0813.2011.00774.x

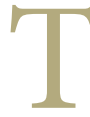
he home ground for the Tamworth Dressage Club (TDC) is at Moonbi, a small village situated $20 \mathrm{~km}$ north of Tamworth, New South Wales (NSW), on the New England Highway. The TDC ground is part of the Moonbi recreational grounds, which are also home to the Kootingal Pony Club, Kootingal Trotting Club, New 